\title{
Quantitative 3D Micro-CT Imaging of Human Lung Tissue
}

\section{Quantitative 3-D-Mikro-CT-Bildgebung von humanem Lungengewebe}

Authors

Affiliations
M. Kampschulte ${ }^{1}$, C. R. Schneider ${ }^{1}$, H. D. Litzlbauer ${ }^{1}$, D. Tscholl² ${ }^{2}$ C. Schneider ${ }^{1}$, C. Zeiner ${ }^{3}$, G. A. Krombach ${ }^{1}$, E. L. Ritman ${ }^{4}$, R. M. Bohle ${ }^{3}$, A. C. Langheinrich ${ }^{5}$

Affiliation addresses are listed at the end of the article.
Key words

- thorax

- CT

tissue characterization

eingereicht 17.12 .2012

akzeptiert 2.6.2013

Bibliography

Dol http://dx.doi.org/

10.1055/s-0033-1350105

Published online: 25.7.2013

Fortschr Röntgenstr 2013; 185 :

869-876 @ Georg Thieme

Verlag KG Stuttgart · New York .

ISSN 1438-9029

\section{Correspondence}

Dr. Marian Kampschulte

Radiologie, Uniklinikum Gießen und Marburg, Standort Gießen Klinikstraße 33

39592 Gießen

Germany

Tel.: ++ 49/06 41/98541815

Fax: ++49/0641/98541809

marian.kampschulte@radiol.

med.uni-giessen.de

\section{Zusammenfassung \\ $\nabla$}

Ziel: Ziel der Arbeit war es, anhand von Mikro-CTUntersuchungen humaner Lungenproben quantitative und morphologische Informationen der Feinstruktur bei vorbestehender Fibrose und Emphysem im Vergleich zu nicht erkranktem Lungengewebe zu gewinnen.

Material und Methoden: Proben von Autopsie- sowie Explantationslungen mit gesicherter Fibrose $(\mathrm{n}=22)$, zentrilobulärem Emphysem $(\mathrm{n}=10)$ bzw. ohne pulmonale Vorerkrankung $(n=22)$ wurden untersucht. Die Proben wurden intravasal kontrastiert oder in ventilierter Stellung fixiert und mit Osmium kontrastiert. Der Gefäß-, Gewebe- und Luftanteil am Gesamtvolumen der untersuchten Proben wurde ermittelt. Zwecks artefaktfreier 3D-Rekonstruktion einzelner Lungenazini wurden Proben mit Emphysem $(n=5)$ bzw. ohne Vorerkrankung $(n=6)$ im Synchrotron-Mikro-CT untersucht. Die Bildgebung wurde durch histologische Aufarbeitung der Proben ergänzt.

Ergebnisse: Für Proben mit gesicherter Fibrose zeigte sich im Vergleich zur Kontrollgruppe eine signifikante Zunahme der Gewebeanteile, begleitet von einer Reduktion belüfteter Areale $(p<0.001)$ sowie eine signifikante Abnahme der Gefäßanteile $(\mathrm{p}<0.02)$. Proben mit vorbestehendem Emphysem zeigten eine signifikante Abnahme des Gewebeanteils bzw. eine Zunahme des Luftanteils am Gesamtvolumen $(p<0.001)$. Die 3-D-Rekonstruktion einzelner Lungenazini ließ sich erfolgreich in nicht erkranktem Lungenparenchym durchführen, versagte jedoch in der Bearbeitung von Daten der Emphysem- oder Fibroselungen.

Schlussfolgerung: Die Mikro-CT von Proben menschlichen Lungengewebes ist technisch durchführbar und liefert quantitative und morphologische Informationen für die Charakterisierung von Lungenpathologien im Vergleich zu nicht erkranktem Lungengewebe.

\section{Abstract \\ $\nabla$}

Purpose: To assess the feasibility of micro-CT for obtaining quantitative volumetric and morphologic information of changes in soft tissue, respiratory tracts and vascularization in fibrotic, emphysematous and non-diseased human lung specimens.

Materials and Methods: Specimens from autopsy or lung explantation with lung fibrosis of UIP pattern $(n=22)$ or centrilobular emphysema $(n=10)$ were scanned by micro-CT and compared to controls $(n=22)$. Imaging was performed subsequent to intravascular contrast enhancement for the assessment of the vascular volume fraction. The soft tissue and air fraction were quantified after the fixation of ventilated lungs followed by tissue contrast enhancement using osmium. Aiming an artifact-free $3 \mathrm{D}$ reconstruction of lung acini, synchrotron-based micro-CT scans of specimens with emphysema $(n=5)$ and non-diseased tissue $(n=6)$ was performed. Micro-CT imaging was complemented by histology for the demonstration of comparable findings.

Results: Quantitative analysis showed a significant increase of the soft tissue fraction, equivalent to a decrease of the air fraction in fibrotic lungs compared to controls $(p<0.001)$ and a significant reduction of the vascular volume fraction compared to controls $(p<0.02)$. Specimens with emphysema demonstrated a significant increase of the air fraction with a decrease in soft tissue compared to controls ( $p<0.001)$. $3 \mathrm{D}$ reconstructions of lung acini worked successfully in non-diseased tissue but failed in fibrotic and emphysematous lungs.

Conclusion: Our findings indicate micro-CT's technical feasibility to assess quantitative and morphological data from diseased and non-diseased human lung specimens. 


\section{Citation Format:}

- Kampschulte M, Schneider CR, Litzlbauer HD et al. Quantitative 3D Micro-CT Imaging of Human Lung Tissue. Fortschr Röntgenstr 2013; 185: 869 - 876

\section{Introduction}

$\nabla$

Micro-computed tomography (micro-CT) has been established as a high-resolution imaging technique and non-destructive method for the investigation of small animals, specimens of biological tissues and implants [ 1 - 4]. Imaging studies of the lung using micro-CT are mostly focused on investigations in small animals invivo as well as ex-vivo. Comparable studies of the human lung are rare. Due to technical limitations such as detector size, micro-CT investigations of the human lung are restricted to the examination of small samples of excised tissue. By generating data sets consisting of isotropic voxels, information regarding spatial arrangement as well as quantitative dimensions of microstructures can be obtained from a $3 \mathrm{D}$ volume as well as from cross sections in any freely selectable spatial direction. Mean intercept length measurements as a proposed but criticized method for $2 \mathrm{D}$ investigations of alveolar parenchyma was comparatively investigated using micro-CT and histology. Furthermore, 3 D image editing techniques such as virtual endoscopy and shrink-wrap algorithms have been employed to describe lung anatomy and pathological changes of small airways and parenchyma in micro-CT data sets [5 - 7]. Quantitative 3D measurements have been applied repeatedly for investigations of vascularization and for the quantification of tissue proliferation and rarefaction in human organs other than the lung $[8,9]$. Such techniques might contribute to the understanding of pathophysiology and natural course of different diseases. Tissue and vascular remodeling processes lead to changes in three-dimensional microarchitecture of lungs with fibrosis or emphysema. Proliferation or rarefaction of lung tissue and airways as well as their spatial arrangement are part of criteria for radiological diagnosis using high-resolution computed tomography (HRCT). Furthermore, threshold-based HRCT densitometry can give a good clinical estimation to score the extent of emphysema and fibrosis. Nevertheless, there is a lack of information how diseased compartments like lung tissue and vessels change their volumetric ratio especially on a microscopic level as it can be achieved using micro-computed tomography. In this study we analyzed micro-CT data sets of human lungs using threshold-based volumetric measurements to quantify fine structures, i.e. tissue, distal respiratory tracts and vasculature and their changes under pathological conditions such as pulmonary fibrosis and emphysema.

\section{Materials And Methods}

$\nabla$

\section{Specimens}

All specimens ( $n=54$ specimens from 13 patients) were acquired from lungs obtained from autopsy $(n=16$ specimens from 6 patients) or lung resection ( $n=38$ specimens from 7 patients). In other words and from a histopathologic point of view, same specimens ( $n=54$ specimens from 13 patients) were obtained from fibrotic human lungs with UIP pattern $(n=22$ specimens from 7 patients) and specimens with centrilobular emphysema ( $n=10$ specimens from 1 patient). Controls were taken from 5 patients ( $\mathrm{n}=9$ specimens) without lung disease and from disease-free regions of 3 patients suffering from $\operatorname{UIP}(n=13$ specimens; $\bullet$ Table 1$)$. - Table 1 reflects the number of lung specimens concerning the histopathologic pattern and the method of contrast enhancement. All specimens were acquired from the Institutes of Pathology at either Gießen or Homburg/Saar University Hospital. Informed consent for lung surgery and morphological investigation was preserved from patients before lung transplantation or for autopsy by next of kin. The study fulfilled the requirements of the Ministries of Science and Ministry of Health (Hessen and Saarland). Histology of all specimens from autopsy and explanted lungs was obtained for diagnostic purposes.

Lung preparation, fixation and osmium staining - group I Lung tissue, i.e. thin alveolar septa, and pulmonary vessels do not give sufficient contrast in native scanning using micro-CT and need to be contrast-enhanced prior to scanning. Therefore, specimens were stained either with osmium or an intravascularly injected contrast medium. Seven lungs of seven patients (group I, see - Table 1) were connected to a tube of a modified Engstrom-type respirator. After recruitment of airways with a peak airway pressure of $40 \mathrm{~cm} \mathrm{H}_{2} \mathrm{O}$ for $40 \mathrm{~s}$, the lungs were ventilated in a volumecontrolled, pressure-limited mode with a positive end-expiratory pressure of $5 \mathrm{cmH}_{2} \mathrm{O}$. The peak pressure was limited to $35 \mathrm{~cm} \mathrm{H}_{2} \mathrm{O}$. The tidal volume was adjusted to reach full lung inflation, the respiration rate was set to $12 / \mathrm{min}$, and the inspiratory-to-expiratory ratio was $1: 2$. Fixation was performed by ventilating the lung with formaldehyde vapor. The fixation process lasted $6 \mathrm{~h}$. This preparation resulted in air-filled lungs with inflated alveoli. Next, cylindrical-shaped specimens with a length of $10 \mathrm{~mm}$ and a diameter of $8 \mathrm{~mm}$ were taken with a sharp mechanical stamp. Tissue speci-

Table 1 Distribution of specimens ( $n=54$ ) according to their histopathological characteristics (columns) and methods of contrast enhancement (rows). Group I (upper row, $n=26$ specimens) reflects the number of osmium-contrasted specimens, group II (lower row, $n=28$ specimens) shows the number of intravascular-contrasted specimens. Air, tissue (group I) and vascular volume fractions (group II) were quantified depending on the specific contrast enhancement method.

Tab. 1 Zuordnung der Proben bezüglich ihrer histolopathologischen Gewebecharakteristika und der Kontrastierungsmethode. Gruppe I (obere Zeile) spiegelt die Anzahl der Proben mit Osmiumkontrastierung wider. Gruppe II (untere Zeile) beziffert die Anzahl der vaskulär kontrastierten Proben. In Abhängigkeit vom Kontrastierungsverfahren wurden Luft-, Gewebe- (Gruppe I) und Gefäßverteilung (Gruppe II) quantifiziert.

\begin{tabular}{|lllc} 
& $\begin{array}{l}\text { fibrosis } \\
\text { (number of specimens) }\end{array}$ & $\begin{array}{l}\text { emphysema } \\
\text { (number of specimens) }\end{array}$ \\
\hline group I - osmium staining & 13 & 10 & 3 \\
group II - intravascular contrast & 9 & 0 & 19
\end{tabular}


mens were dried with a critical point dryer to remove excessive fluid without tissue deformation. All specimens ( $n=26$; controls, fibrosis and emphysema) of group I (see 0 Table 1) were immersed in tubes filled with a solution of $1 \%$ osmium tetroxide. The tubes were rotated for three hours. Afterwards, the specimens were washed threefold in purified water to remove excess osmium and dried again by critical point drying.

\section{Intravascular contrast application - group II}

In those lungs in which intravascular contrast medium was applied, segment 8 from the left and/or the right lung $(n=10)$ of 6 individuals was examined (group II, see $\bullet$ Table 1 ). In order to assess tissue vascularization as a ratio between vascular volume and soft tissue, we abstained from lung fixation in a ventilated position in group II. The segmental pulmonary artery of fibrotic and control lungs was blocked using a balloon catheter with a cuff diameter of $6 \mathrm{~mm}$ and perfused with heparinized saline solution until the venous effluent was free from blood. A contrast medium consisting of a plumbiferous compound polymer (Microfil ${ }^{\circledR}$ MV-122, Flow Tech, Carver, MA, USA) was infused with a nominal pressure of $\sim 30 \mathrm{~mm}$ Hg. After polymerization of the contrast medium, lung specimens of group II $(n=28)$ were taken as described for group I, fixed in formalin and dried as mentioned above.

\section{Image acquisition: Micro-CT}

All specimens were scanned in a micro-computed tomograph manufactured by SkyScan (SkyScan 1072_80kV; Kontich, Belgium). Micro-CT was performed with a tungsten microfocus tube using a voltage of $80 \mathrm{kVp}$ and $100 \mu \mathrm{A}$. Specimens placed on a rotating stage were scanned over 180 degrees in increments of $0.45^{\circ}$. The detector of the system is equipped with a 12-bit digital CCD camera with a resolution of $1024 \times 1024$ pixels. Geometric magnification of the system is determined by object-source distance, which can be decreased resulting in an up to 80-fold magnification to provide a minimum voxel size of $(8 \mu \mathrm{m})^{3}$. A modified Feldkamp cone-beam reconstruction algorithm was used. Each cross sectional image consisted of a matrix of $1024 \times 1024$ pixels with a cubic voxel size of $(14 \mu \mathrm{m})^{3}$.

\section{Image acquisition: Synchrotron micro-CT}

Binarization of polychromatic micro-CT data causes volumetric non-significant micro-erosions of thin alveolar walls with overestimation of single acini by artificially combining neighboring acini. Therefore, randomly selected lung specimens from controls $(n=6)$ and patients with severe emphysema $(n=5)$ were scanned with the micro-CT at the X2B beam-line at the National Synchrotron Light Source (NSLS) at the Brookhaven National Laboratories in Long Island, New York. The specimen was rotated $360^{\circ}$ about its central axis in increments of 0.25 degrees, resulting in 1440 projections. Each pixel provided values with a 16-bit grayscale. Specimens were scanned under identical conditions with a nominal $18 \mathrm{keV}$ photon energy with a bandwidth of $50 \mathrm{eV}$ and an isotropic voxel size of $(4 \mu \mathrm{m})^{3}$.

\section{Histopathology}

After CT scanning, all specimens were routinely processed, embedded in Paraffin, serial sectioned at a slice thickness of $6 \mu \mathrm{m}$ and stained with hematoxylin-eosin and Goldner's trichrome. Histological sections were examined by light microscopy and digitized afterwards.
Quantitative image analysis, comparisons of

Histopathology and micro-CT imaging

Data analysis was carried out by the Analyze software package (Biomedical Imaging Resource, Mayo Foundation, USA, version 9.0).

As a first step, cubic subregions with a side length of $4 \mathrm{~mm}$ were taken from each data set for further standardized analysis. Cutoff values of the CT image grayscale were individually selected by thresholding to discriminate intravascular contrast agent, soft tissue and air. The air fraction (AF) was measured from group I ( $\bullet$ Table 1 ) and describes the volume fraction of air within a volume of interest containing soft tissue and air and was calculated as follows:

$\mathrm{AF}(\%)=3 \mathrm{D} \_\mathrm{TAV} / 3 \mathrm{D} \_\mathrm{TV} * 100 \%$;

where 3D_TAV (total air volume) represents the sum of all voxels marked as air and 3D_TV (total volume) represents the whole volume of the specimen. The tissue fraction (TF), which can be considered as the calculative opposite of air fraction, was measured from group I ( $\bullet$ Table 1 ) and calculated as follows:

$\mathrm{TF}(\%)=100-\mathrm{AF}$.

The vascular volume fraction was measured from group II ( $\bullet$ Table 1) and describes the volume fraction of intravascular contrast agent within a volume of interest containing air, soft tissue and contrast-enhanced vasculature.

VVF $(\%)=3 D \_T C A V / 3 D \_T V * 100 \%$;

where 3D_TCAV (total contrast agent volume) represents the sum of all voxels marked as contrast agent and 3D_TV (total volume) represents the whole volume of the specimen.

Digitized histological sections were imported into Analyze and matched with the corresponding micro-CT data by a side-toside visual analysis of slices in the same position. Therefore, multiplanar reformation (MPR) was performed in the coronal, sagittal and oblique view with a slice thickness of $14 \mu \mathrm{m}$. Three-dimensional reconstruction of distal air tracts was carried out using a "shrink wrap" algorithm, followed by a seed point-based centerline reconstruction algorithm of the acinus as previously described by Litzlbauer et al. [8]. In short, the specimen was virtually wrapped, i.e. segmented, from surrounding air to isolate airways from air outside of the specimen. Next, a seed point was set in the terminal bronchiolus wherefrom an algorithm was carried out to draw branching centerlines into the acinus. Based on the resulting centerline trees, single acini can be reconstructed.

\section{Statistical analysis}

Statistical analysis was performed using JMP 6.0. Differences between groups were detected using One-way ANOVA and Tukey-Kramer test. Statistical significance was considered for $\mathrm{p}$-values $<0.05$. Data are presented as mean \pm SD.

\section{Results}

\section{$\boldsymbol{\nabla}$}

Quantitative analysis of tissue and air

The tissue and air fractions were significantly different in specimens with fibrosis or emphysema compared to controls $(\diamond$ Fig. 1,2). Fibrotic lung specimens demonstrated a significant augmentation of the tissue fraction (fibrosis $87 \pm 10 \%$ vs. controls $17 \pm 9 \%$; $<0.001$ ) with a complementary reduction of the air fraction (fibrosis $13 \pm 8 \%$ vs. controls $83 \pm 23 \%$; p < 0.001 ) in group I ( $\bullet$ Fig. 1, 2). In contrast, human lung specimens with centrilobular emphysema demonstrated a significant increase in air fraction (emphysema $98 \pm 0.8 \%$ vs. controls $83 \pm 23 \%$; p < 0.001 ) and a sig- 


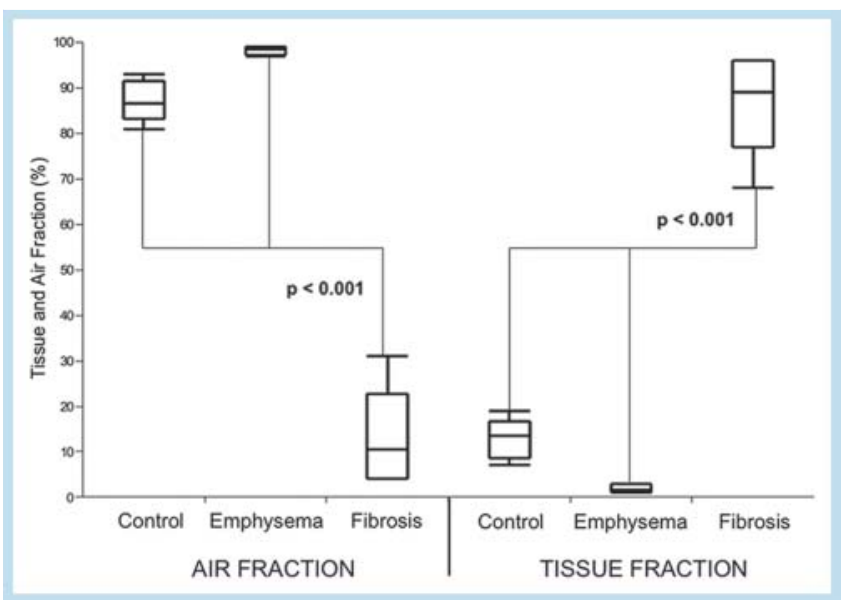

Fig. 1 Group I: A significant increase of the tissue fraction with a concomitant significant decrease of the air fraction (both $p<0.001$ ) is present in fibrosis compared to controls. In specimens with emphysema, a reverse situation with a significant decrease of the tissue fraction and a concomitant significant increase in the air fraction (both $p<0.001$ ) can be seen.

Abb. 1 Gruppe I: In der Fibrose-Subgruppe war ein signifikant höherer prozentualer Gewebsanteil bzw. eine signifikante Minderung des Atemwegsanteils (beides $p<0.001$ ) im Vergleich zur Kontrollgruppe zu verzeichnen. Proben mit nachgewiesenem Emphysem wiesen ein umgekehrtes Muster mit signifikanter Minderung des prozentualen Gewebsanteiles bzw. signifikanter Zunahme des Atemwegsanteils (beides $p<0.001$ ) im Vergleich zur Kontrollgruppe auf. nificant decrease of the tissue fraction compared to the controls ( 2 $\pm 0.9 \%$ vs. controls $17 \pm 9 \%$; $<0.001$, ○ Fig. $1-3$ ) in group I.

\section{Quantitative analysis of vessels}

Simultaneously, specimens with lung fibrosis of group II showed a significant reduction of the vascular volume fraction compared to the controls (fibrosis $4 \% \pm 2 \%$ vs. control $14 \% \pm 8 \%$; $<<0.02$ ( $\bullet$ Fig.4)). Independent of the differences in vascular volume fraction, contrast-filled vessels showed a specific morphological discrepancy: vessels in non-fibrotic lungs exhibited a clear rectilinear distribution whereas vessels in fibrotic regions featured a corkscrew-like and retracted pattern ( $\bullet$ Fig. $\mathbf{6})$.

\section{Histology}

As a prerequisite for inclusion in the study, histopathological findings had to fulfill the requirements of i) fibrosis, ii) emphysema or iii) non-diseased lung. Mild phenotype, mix-type diseases or other unclear or indistinct diagnosis was strictly excluded. Side-by-side presentation of micro-CT images and histology from comparable regions within same specimens depicted structures such as bronchi, vessels and soft tissue ( $\bullet$ Fig. 5). We did not observe any disruption or deformation as a result of specimen preparation. A precise visualization of the lung fine structure was possible with a spatial resolution of $(14 \mu \mathrm{m})^{3}$ voxel size.

\section{Reconstruction of distal airways}

Three-dimensional reconstruction of distal airways ( $\bullet$ Fig. 7 )
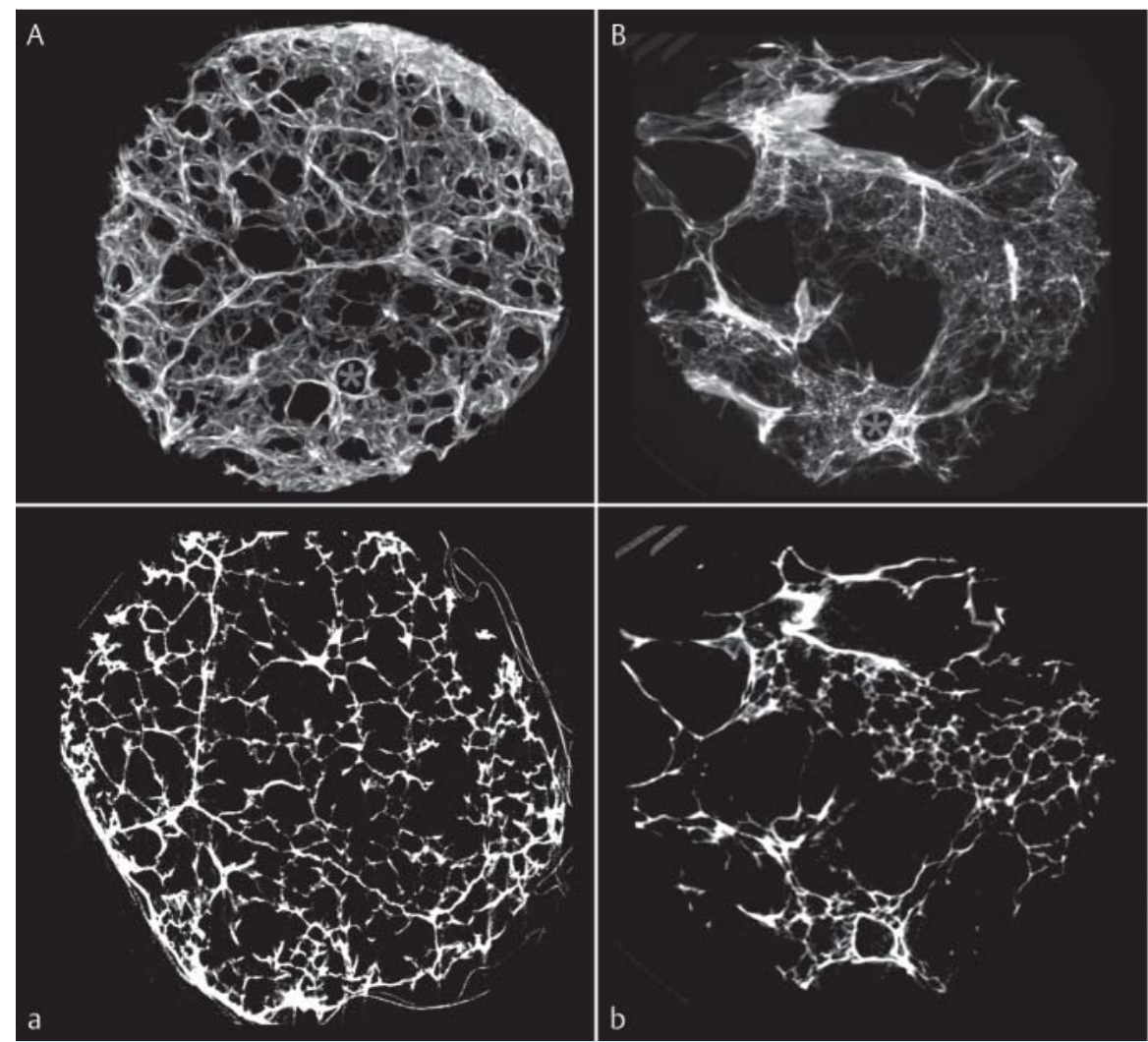

Abb. 2 Maximum Intensitätsprojektionen (A, B, C) sowie Einzelschnittbilder $(\mathbf{a}, \mathbf{b}, \mathbf{c})$ von Kontrollen $(\mathbf{A}, \mathbf{a})$, Emphysem $(\mathbf{B}, \mathbf{b})$ und Fibrose $(\mathbf{C}, \mathbf{c})$ demonstrieren die Veränderungen der Lungenfeinstruktur bzgl. Menge und Verteilung lufthaltiger Areale bzw. Gewebe bei einer Ortsauflösung von $(14 \mu \mathrm{m}) 3$. Wie in $\otimes$ Abb. 1 bereits quantitativ aufgeführt, sind Verlust (B, b) bzw. Zunahme (C, c) des Lungengewebes mittels Micro-CT klar identifizierbar. 


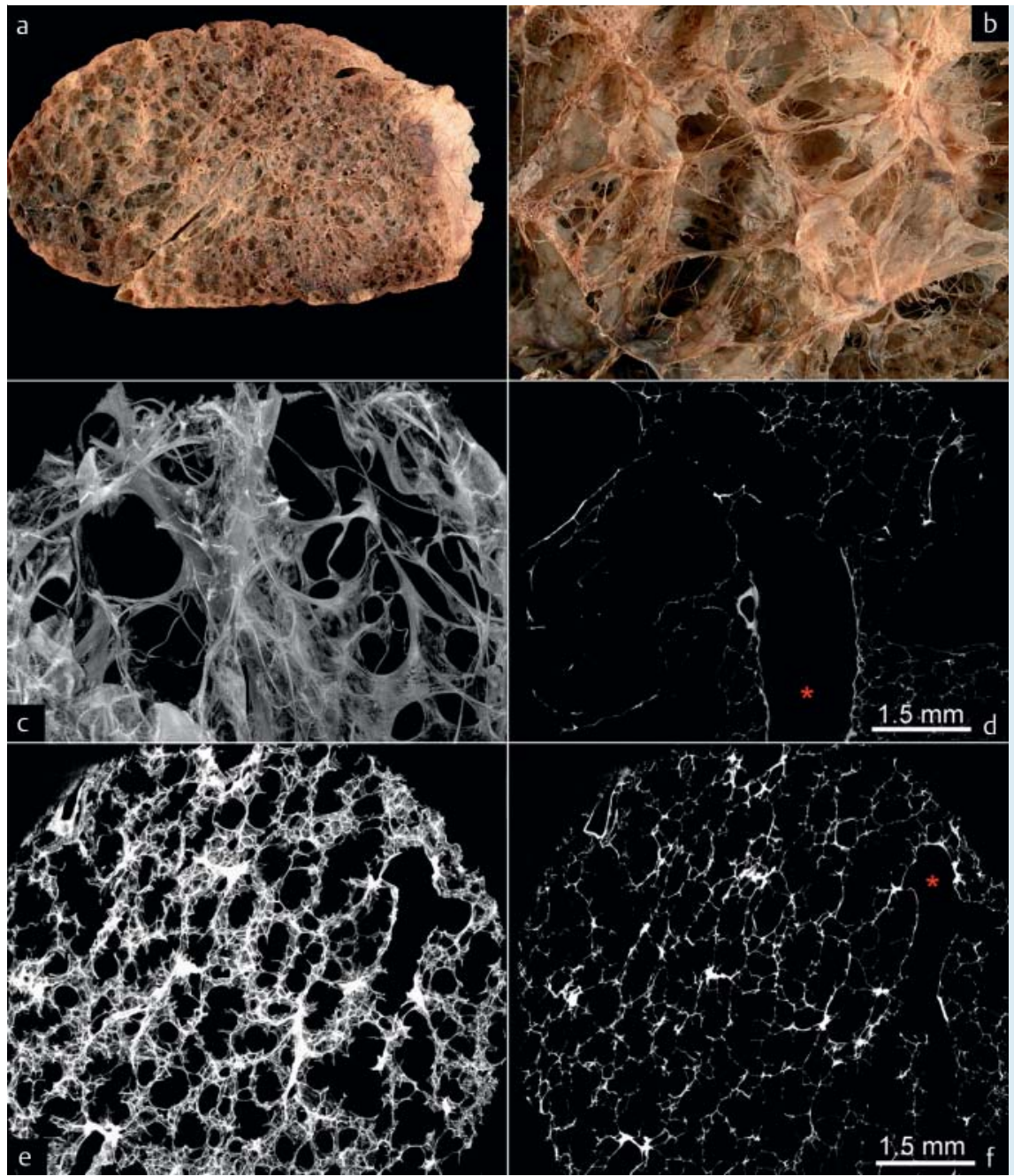

Fig. 3 Macroscopic image of an emphysematous lung $\mathbf{a}$ and magnification $\times 5 \mathbf{b}$ after hot formalin vapor fixation. Synchrotron micro-CT images (c, MIP and $\mathbf{d}$, cross sectional image at $(4 \mu \mathrm{m})^{3}$ voxel size) also demonstrate the emphysematous character with overexpansion of terminal airways resulting from loss of fine lung structure compared to controls (e, MIP and $\mathbf{f}$, single-slice).

Abb. 3 Makroskopisches Präparat einer Emphysemlunge a sowie in 5 -facher Vergrößerung nach Formalindampf-Fixierung b. Gemeinsam mit der Synchrotron-Bildgebung mit MIP c bzw. Einzelschnittbild $\mathbf{d}$ werden Emphysemaspekte durch Überblähung und Zerstörung des Lungenparenchyms nach bei einer Auflösung von $(4 \mu \mathrm{m})^{3}$ übereinstimmend nachgewiesen und lassen sich von den Kontroll-Lungen klar abgrenzen (E, MIP und $\mathbf{F}$, Einzelschnitt).

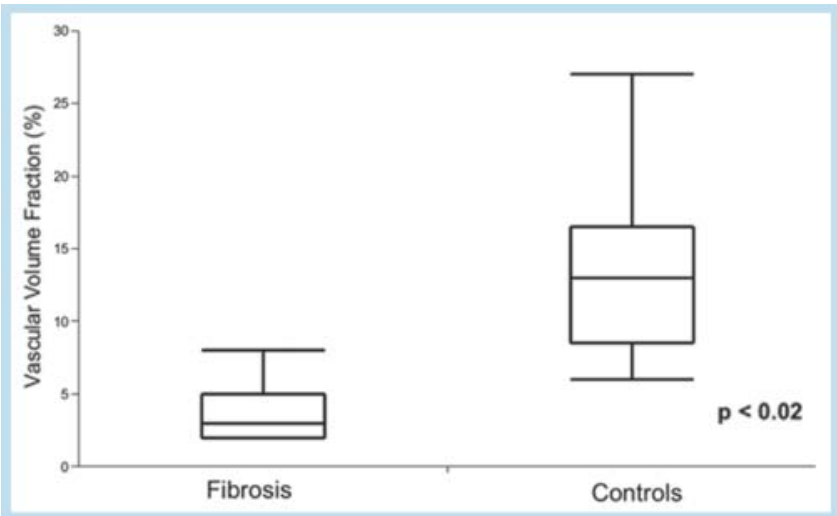

Fig. 4 Group II: After contrast perfusion, the vascular volume fraction also showed significant differences between controls and fibrotic lung tissue $(p<0.02)$ with a reduction of vascularization in fibrotic lung specimens.

Abb.4 Gruppe II: Nach intravaskulärer Kontrastierung zeigten sich signifikante Unterschiede zwischen Fibrose- und Kontrollgruppe mit Verringerung des Gefäßanteils in der Fibrosegruppe $(p<0.02)$.

using a seed point algorithm enabled the visualization of single lung acini in control lungs. Due to the destruction of alveolar tissue in emphysema, narrowing and concomitant overexpansion of distal airways, it was impossible to isolate a single lung acinus in any emphysematous lung specimen using the described approach. The soft tissue proliferation in fibrosis resulted in a filling of small airways with pathophysiological destruction of the anatomy of the lung fine structure.

\section{Discussion}

$\nabla$

The goal of the current work was to give a first methodological approach for a quantitative, volumetric $3 \mathrm{D}$ examination of the human lung fine structure under physiological and different pathological conditions using micro-CT. Our study has revealed that micro CT can assess the extent of tissue alterations in emphysema as well as tissue and vascular alterations in lung fibrosis when using a threshold-based volumetric quantification approach.

\section{Quantitative analysis of tissue}

Results from animal experiments using micro-CT have proven its ability and value for three-dimensional imaging and morphometric analysis of alveolar tissue [6], for the detection and quantification of interstitial lung edema after perfusion with endotoxin [10], and for in-vivo and ex-vivo imaging and quantification in experimental models of lung fibrosis [11-13]. Imaging of the lungs in small laboratory animals can be done in a respiratorygated manner in-vivo or after ligation of the trachea or major 


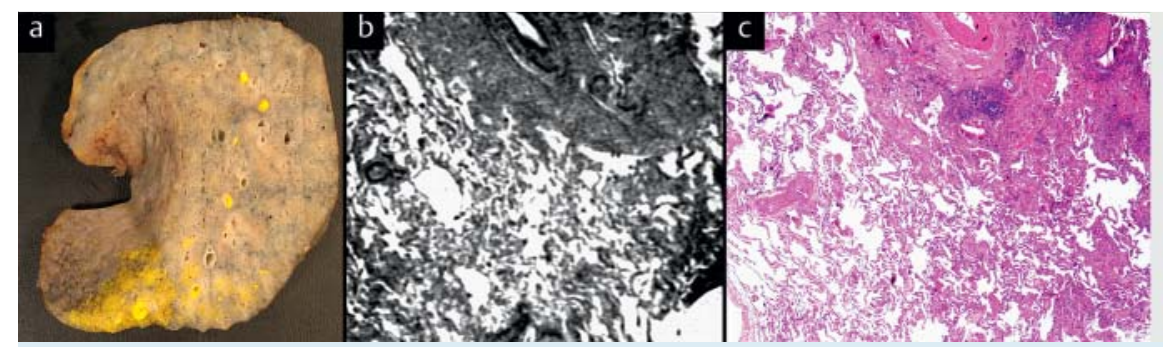

Fig. 5 Macroscopic image a and grayscale inverted micro-CT single slice $\mathbf{b}$ demonstrating increased soft tissue content in fibrotic lung tissue. Co-localized histology of the same specimen (c, HE staining, magnification $\times 10$ ) confirmed the micro-CT findings with a comparable architecture of lung tissue.

Abb.5 Makroskopisches Präparat a und Grauwert-invertierter Micro-CT Einzelschnitt $\mathbf{b}$ demonstrieren die Zunahme des Lungengewebes in der Fibrosegruppe. Histologie (c, HE-Färbung, 10-fach vergrößert) und Mikro-CT in übereinstimmenden Arealen belegen die vergleichbare Gewebsarchitektur in den verschiedenen Modalitäten.
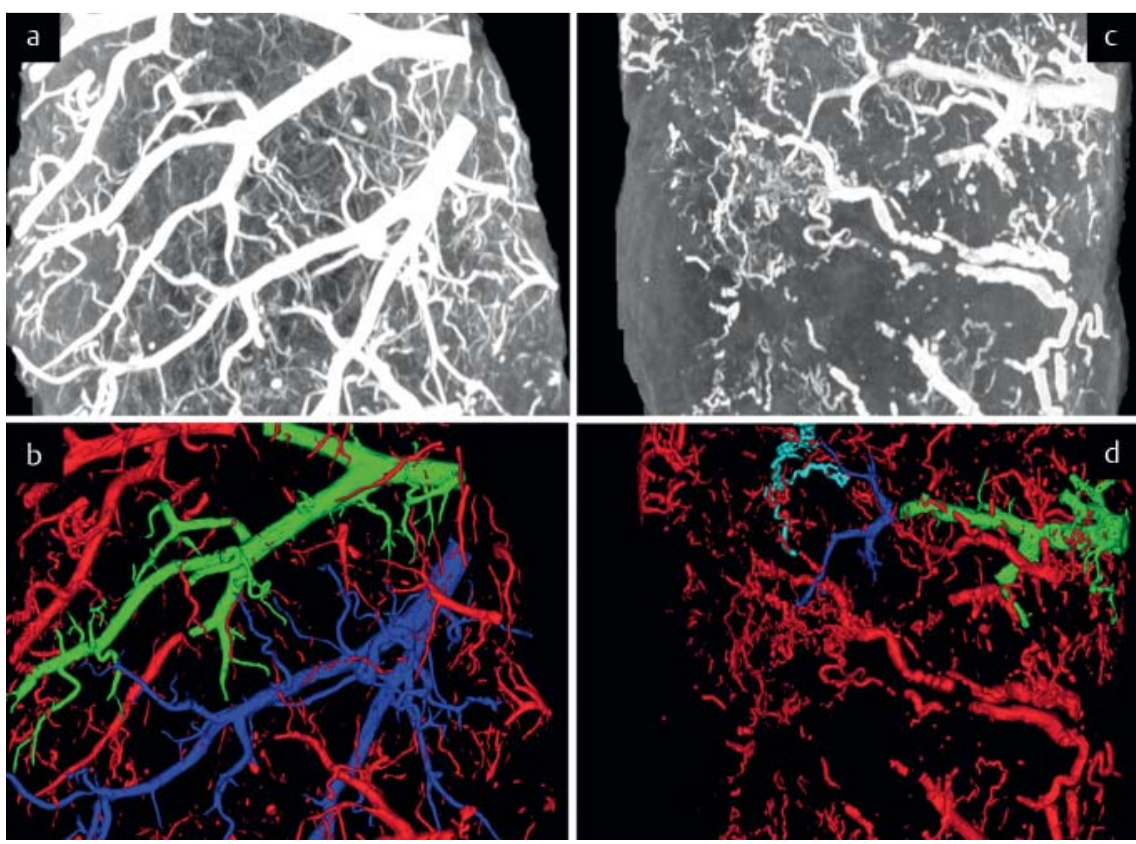

Fig. 6 MIP a, $c$ and volume-rendered micro-CT images $\mathbf{b}, \mathbf{d}$ in controls $\mathbf{a}, \mathbf{b}$ and fibrotic lungs $\mathbf{c}, \mathbf{d}$ : After intravascular contrast perfusion (Microfil), fibrotic lungs demonstrate a significant decrease in the total vascular volume fraction compared to controls as presented in $\bullet$ Fig. 4. Moreover, the vessels of fibrotic lung specimens show irregular branching as well as a typical corkscrew-like pattern.

Abb. 6 MIP a, $\mathrm{c}$ und volume rendered micro-CT Bildgebung $\mathbf{b}, \mathbf{d}$ von Kontroll- $\mathbf{a}, \mathbf{b}$ und Fibroselungen c, d: Wie in $\bullet$ Abb. 4 quantitativ dargestellt, ergibt sich nach intravaskulärer Kontrastierung das Bild einer verminderten Vaskularisation in der Fibrosegruppe. Zusätzlich zeigen die Gefäße der Fibroselunge eine veränderte Architektur mit einem Korkenzieher-förmigen Muster und einer verändertem Aufzweigungsanordnung. bronchi ex-vivo. For a realistic and detailed analysis, tissue specimens of the human lung have to be prepared carefully and laboriously to maintain correct anatomical proportions of tissue and air spaces. Therefore, the technique depends on a standardized preparation technique, scanning and post-processing protocols. In the past, different methods have been developed to prepare human lung tissue prior to radiologic examination and for the visualization of the lung micro-architecture [14-17]. Up to now, these techniques are still accepted and used [7, 18]. Quantitative micro-CT studies of human lung pathologies focus most often on airway alterations in emphysema. $2 \mathrm{D}$ measurements like mean linear intercept, and the quantification of terminal bronchioles in number and diameter provide insight into the rarefaction of small airways and the different temporal onset of narrowing and collapse of terminal bronchioles versus the emphysematous destruction of alveolar tissue [18, 19]. Nevertheless, it does not quantify the loss of tissue. Ikura et al. [20] demonstrated synchrotron-based micro-CT imaging of human lung specimens with different histopathological patterns as cellular alveolitis, diffuse alveolar damage, and pulmonary hemorrhage. They demonstrated a good correlation between histology and micro-CT findings. Our study broadens these results with corresponding findings in fibrosis and emphysema representing common dis- eases of the human lung. By gradually executing a workflow algorithm consisting of formalin vapor fixation, osmium staining, critical point drying, micro-CT imaging and semi-automated three-dimensional quantification, we were able to compare the alterations of air space vs. tissue volume proportions in fibrotic, emphysematous and non-diseased lung tissue. Three-dimensional micro-CT imaging and the quantification of human lung specimens is able to quantify the soft tissue fraction and demonstrates a significant soft tissue augmentation in fibrotic lungs and its loss in emphysematous lungs compared to controls. These findings are consistent with the histopathological background of the described lung alterations.

\section{Quantitative analysis of microvessels in lung fibrosis}

Vascular remodeling is a known phenomenon in IPF lungs and the quantification of small pulmonary vessels in human lung fibrosis has been controversially described with augmented vascular density [21 -23] in non-fibrotic lesions and reduced vascular density and size [23-25] in fibrotic areas. Three-dimensional imaging of pulmonary structures based on serial sections, immunostaining, digitization and $3 \mathrm{D}$ reconstruction has been described by Ebina et al. [23, 26], who found a reduction of vascularization compared to non-fibrotic lung specimens. In contrast, 

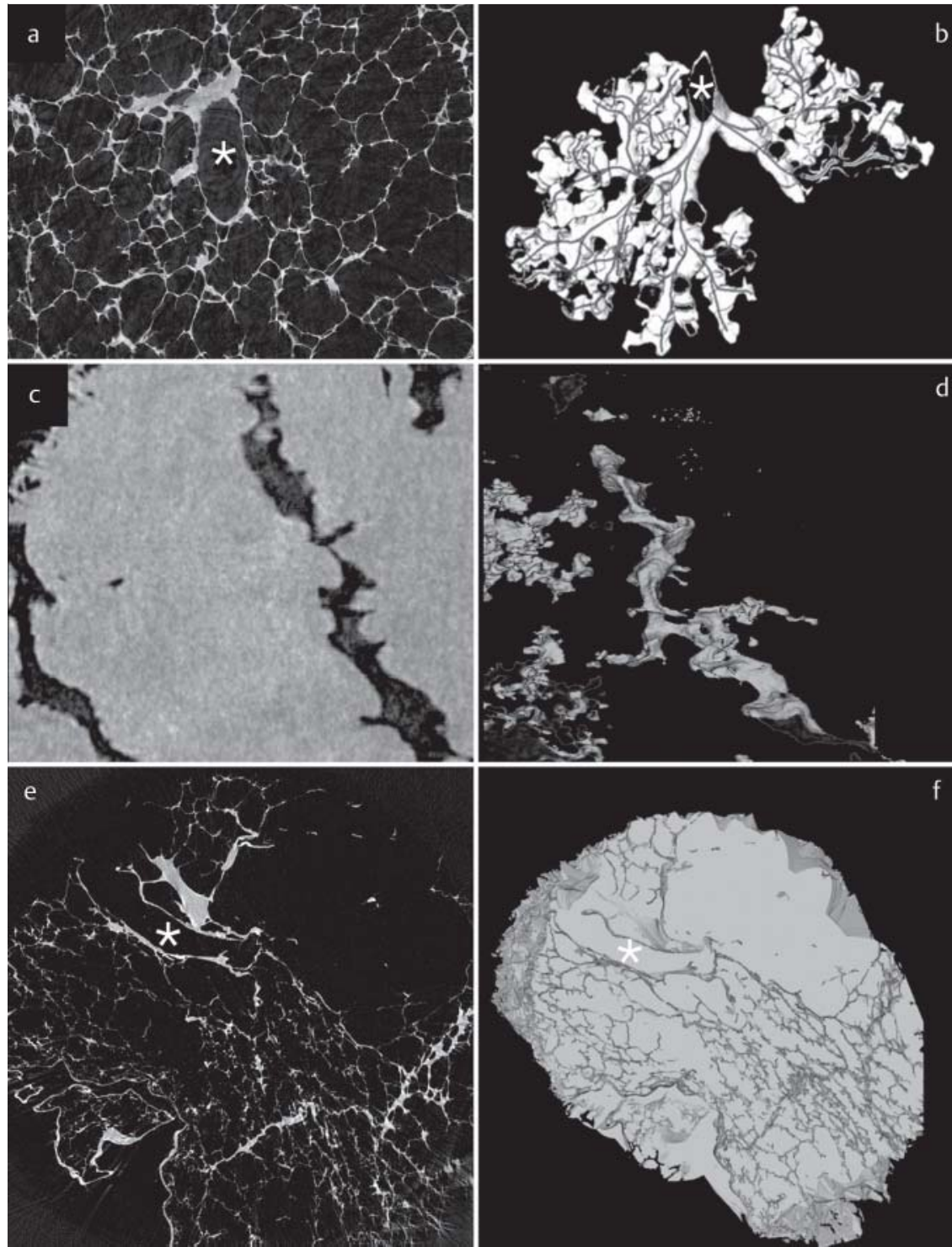

b Fig. 7 Cross sectional images and volume-rendered micro-CT images of controls (synchrotronbased micro-CT: a, b), fibrosis (SkyScan 1072: c, d) and emphysema (synchrotron-based micro-CT: e, f): Using a combined "shrink-wrap" and centerline reconstruction algorithm, it is possible to identify and separate a single lung acinus in a control lung specimen. In contrast, the architecture of conducting airways in fibrotic tissue is distorted. There is no air left in distal small airways due to soft tissue proliferation. In emphysema, the architecture of airways exhibits dilation, narrowing, destruction and coalescence of neighboring acini. The identification and reconstruction of a single acinus was impossible in both cases.

Abb.7 Einzelschnitt und volume-rendered micro$\mathrm{CT}$ von Kontroll-Lungen (Synchotron-Mikro-CT: a, b), Fibrose (SkyScan 1072: c, d) und Emphysem (Synchotron-Mikro-CT: e, f): Unter Anwendung einer Kombination von „Versiegelung“- und Mittellinien-Rekonstruktionsalgorithmen lassen sich in der Kontrollgruppe einzelne Azini rekonstruieren und graphisch abbilden. Durch die Veränderung der Lungenfeinstruktur in Fibrose und Emphysem mit obliterierten Azini bzw. verengten terminalen Bronchiolen und überblähten und zerstörten Azini lassen sich diese terminalen Atemwege nicht rekonstruieren.
micro-CT is a fast and reliable method for non-destructive vessel imaging. It has shown repeatedly its potency for quantitative imaging of small vessels in different models of vascular alterations [27-30]. In our study, lung specimens of advanced IPF showed a decreased vascular volume compared to the controls, supporting the findings of Ebina et al. To our knowledge this is the first study that quantifies small pulmonary vessels in a nondestructive manner using vascular contrast-enhanced micro-CT imaging in human lung tissue.

\section{Reconstruction of distal airways}

Virtual endoscopy as well as $2 \mathrm{D}$ morphometry in $3 \mathrm{D}$ micro-CT data sets of emphysematous lung specimens have contributed to the understanding of airway remodeling in emphysema and its impact on ventilation but do not image changes on the acinary level. To overcome this issue, reconstruction of the human lung acinus was previously demonstrated by Litzlbauer et al. who described a method to measure the length and diameter of terminal bronchioli as well as the surface and volume of acini [5]. In our study, the application of this technique to samples with the same physicochemical preparation but different pathologies turned out to be unsuccessful. The destruction of acinary fine structure with coalescence of acini and overexpansion in emphysema as well as the filling of small airways in fibrosis led to a failure of the method since the required objects, i.e. single acini, were lacking or destroyed.

\section{Conclusion}

\section{$\nabla$}

Micro-CT demonstrates the fine structure of the human lung in $3 \mathrm{D}$ and assesses quantitative information in human lung specimens with fibrotic or emphysematous tissue alteration namely vessel density, volume and distribution of connective tissue and air. Quantitative micro-CT should be considered as an additional tool for ex-vivo studies of human lung pathologies. Further research on the value of quantitative information obtained from micro-CT of lung specimens is warranted. A combination of the described tissue preparation technique in whole lungs with HRCT followed by micro-CT might provide valuable information since micro-CT exceeds HRCT's spatial resolution up to 100 times. A direct comparison between HRCT and micro-CT findings might show the potential to unscramble HRCT patterns suffering from partial volume effects and increase knowledge to be used for the 
interpretation of HR-CT. Another conceivable application of this technique can be seen in the scanning of biopsies prior to histology. This approach might as well be considered a valuable adjunct to histopathology by contributing quantitative information on the three-dimensional manifestation of pulmonary diseases.

\section{Affiliations}

Department of Radiology, University Hospital Giessen and Marburg, Gießen 2 Department of Thoracic and Cardiovascular Surgery, Saarland University, Homburg, Germany

Department of Pathology, Saarland University, Homburg, Germany

${ }^{4}$ Department of Physiology and Biomedical Engineering, Mayo Clinic College of Medicine, Rochester, MN

Department of Radiology, BGU Clinic, Frankfurt/Main, Germany

\section{Acknowledgements}

We would like to thank David L Hansen, Diane R Eaker, Andrew L Vercnocke and Steven M Jorgensen of Mayo Clinic College of Medicine, Gunhild Martels, Justus-Liebig University of Giessen for technical assistance. The investigation was supported in part by NIH grant EB000305 at Mayo Clinic College of Medicine. Use of the National Synchrotron Light Source, Brookhaven National Laboratory, was supported by the U.S. Department of Energy, Office of Science, Office of Basic Energy Sciences, under Contract No. DE-AC02-98CH10886. Use of the Advanced Photon Source was supported by the U.S. Department of Energy, Office of Science, Basic Energy Sciences, under Contract No. W-31-109-Eng-38.

\section{References}

1 Bag S, Schambach SJ, Boll H et al. Aktueller Stand der Mikro-CT in der experimentellen Kleintierbildgebung. Fortschr Röntgenstr 2010; 182: $390-403$

2 Jin GY, Bok SM, Han YM et al. Effectiveness of rosiglitazone on bleomycin-induced lung fibrosis: Assessed by micro-computed tomography and pathologic scores. Eur J Radiol 2011; 81: 1901 - 1906

3 Op Den Buijs J, Bajzer Z, Ritman EL. Branching morphology of the rat hepatic portal vein tree: a micro-CT study. Ann Biomed Eng 2006; 34: $1420-1428$

4 Schulman J, Meyer-Lindenberg A, Goblet F et al. Phantomuntersuchungen an einem hochauflösenden CT zur Ex-vivo-Darstellung von degradierbaren Magnesiumimplantaten und simulierten periimplantären Knochenschichten in Kaninchentibiae. Fortschr Röntgenstr 2012; 184: 455 - 460

5 Litzlbauer HD, Korbel K, Kline TL et al. Synchrotron-based micro-CT imaging of the human lung acinus. Anat Rec (Hoboken) 2010; 293: $1607-1614$

6 Litzlbauer HD, Neuhaeuser C, Moell A et al. Three-dimensional imaging and morphometric analysis of alveolar tissue from microfocal X-raycomputed tomography. Am J Physiol Lung Cell Mol Physiol 2006; 291 : L535 - L545

7 Watz H, Breithecker A, Rau WS et al. Micro-CT of the human lung: imaging of alveoli and virtual endoscopy of an alveolar duct in a normal lung and in a lung with centrilobular emphysema-initial observations. Radiology 2005; 236: 1053-1058

8 Langheinrich AC, Kampschulte M, Crossmann C et al. Role of computed tomography voxel size in detection and discrimination of calcium and iron deposits in atherosclerotic human coronary artery specimens. J Comput Assist Tomogr 2009; 33: 517 - 522

9 Langheinrich AC, Stolle C, Kampschulte $M$ et al. Diagnostic Value of ExVivo Three-Dimensional Micro-Computed Tomography Imaging of Primary Nonhematopoietic Human Bone Tumors: Osteosarcoma versus Chondrosarcoma. Acta Radiol 2008: 1-8

10 Langheinrich AC, Leithauser B, Greschus $S$ et al. Acute rat lung injury: feasibility of assessment with micro-CT. Radiology 2004; 233: $165-$ 171

11 Namati E, Thiesse J, Sieren JC et al. Longitudinal assessment of lung cancer progression in the mouse using in vivo micro-CT imaging. Med Phys 2010; 37: $4793-4805$

12 Johnson $K A$. Imaging techniques for small animal imaging models of pulmonary disease: micro-CT. Toxicol Pathol 2007; 35: 59-64

13 Lee HJ, Goo JM, Kim NR et al. Semiquantitative measurement of murine bleomycin-induced lung fibrosis in in vivo and postmortem conditions using microcomputed tomography: correlation with pathologic scores-initial results. Invest Radiol 2008; 43: 453-460

14 Mittermayer C, Wybitul K, Rau WS et al. Standardized fixation of human lung for radiology and morphometry; Description of a "two chamber"-system with formaldehyde vapor inflation. Pathol Res Pract 1978; 162: $115-130$

15 Nettum JA. Bronchoalveolar casting using formalin-fixed canine lungs and a low viscosity silicone rubber. Anat Rec 1993; 236: $408-410$

16 Rau WS, Hauenstein K, Mittermayer C et al. A simple and rapid method for postmortem radiographic investigation of lung fine structure. Pathol Res Pract 1980; 170: 426-432

17 Rau WS, Hauenstein K, Volk P et al. Die röntgenologische Feinstruktur der Lunge. II. Gefrierhärtung isolierter Lungen in flüssigem Stickstoff Fortschr Röntgenstr 1980; 133: 400 - 405

18 McDonough JE, Yuan R, Suzuki M et al. Small-airway obstruction and emphysema in chronic obstructive pulmonary disease. N Engl J Med 2011; 365: $1567-1575$

19 Hogg JC, McDonough JE, Sanchez PG et al. Micro-computed tomography measurements of peripheral lung pathology in chronic obstructive pulmonary disease. Proc Am Thorac Soc 2009; 6: 546- 549

20 Ikura H, Shimizu K, Ikezoe J et al. In vitro evaluation of normal and abnormal lungs with ultra-high-resolution CT. J Thorac Imaging 2004; 19: $8-15$

21 Keane MP, Arenberg DA, Lynch JP et al. The CXC chemokines, IL-8 and IP-10, regulate angiogenic activity in idiopathic pulmonary fibrosis. J Immunol 1997; 159: 1437 - 1443

22 Turner-Warwick M. Precapillary Systemic-Pulmonary Anastomoses. Thorax 1963; 18: 225 - 237

23 Ebina M, Shimizukawa M, Shibata $N$ et al. Heterogeneous increase in CD34-positive alveolar capillaries in idiopathic pulmonary fibrosis. Am J Respir Crit Care Med 2004; 169: 1203 -1208

24 Coalson IJ. The ultrastructure of human fibrosing alveolitis. Virchows Arch A Pathol Anat Histol 1982; 395: 181 - 199

25 Gracey DR, Divertie MB, Brown AL et al. Alveolar-capillary membrane in idiopathic interstitial pulmonary fibrosis. Electron microscopic study of 14 cases. Am Rev Respir Dis 1968; 98: 16-21

26 Ebina M, Yaegashi H, Takahashi T et al. Distribution of smooth muscles along the bronchial tree. A morphometric study of ordinary autopsy lungs. Am Rev Respir Dis 1990; 141: $1322-1326$

27 Jorgensen SM, Demirkaya O, Ritman EL. Three-dimensional imaging of vasculature and parenchyma in intact rodent organs with X-ray microCT. Am J Physiol 1998; 275: H1103-H1114

28 Kantor B, Kwon HM, Ritman EL et al. Images in Cardiology Imaging the coronary microcirculation: 3D micro-CT of coronary vasa vasorum. Int J Cardiovasc Intervent 1999; 2: 79

29 Langheinrich AC, Bohle RM, Breithecker A et al. Mikro-Computertomografie von Blutgefäßen parenchymatöser Organe und von Lungenalveolen. Fortschr Röntgenstr 2004; 176: 1219-1225

30 Ritman EL. Micro-computed tomography of the lungs and pulmonaryvascular system. Proc Am Thorac Soc 2005; 2: 477-480, 501 